\title{
Capsaicin from chili (Capsicum spp.) inhibits vascular smooth
}

\section{muscle cell proliferation [version 1; peer review: 2 approved, 1}

\section{approved with reservations]}

\author{
Rongxia Liu'1,2, Elke H. Heiss¹, Dean Guo², Verena M. Dirsch¹, Atanas G. Atanasov ${ }^{1}$ \\ ${ }^{1}$ Department of Pharmacognosy, University of Vienna, Vienna, Austria \\ ${ }^{2}$ Shanghai Research Center for Modernization of Traditional Chinese Medicine, National Engineering Laboratory for TCM \\ Standardization Technology, Shanghai Institute of Materia Medica, Shanghai Institutes for Biological Sciences, Chinese Academy of \\ Sciences, Shanghai, China
}

V1 First published: 27 Jan 2015, 4:26

https://doi.org/10.12688/f1000research.6007.1

Latest published: 27 Jan 2015, 4:26

https://doi.org/10.12688/f1000research.6007.1

\section{Abstract}

Accelerated vascular smooth muscle cell (VSMC) proliferation is implied in cardiovascular disease and significantly contributes to vessel lumen reduction following surgical interventions such as percutaneous transluminal coronary angioplasty or bypass surgery. Therefore, identification and characterization of compounds and mechanisms able to counteract VSMC proliferation is of potential therapeutic relevance. This work reveals the anti-proliferative effect of the natural product capsaicin from Capsicum spp. by quantification of metabolic activity and DNA synthesis in activated VSMC. The observed in vitro activity profile of capsaicin warrants further research on its mechanism of action and potential for therapeutic application.

\section{Keywords}

Capsaicin , vascular smooth muscle cells, restenosis, proliferation

\section{Open Peer Review}

Approval Status ?

$\begin{array}{llll}1 & 2 & 3\end{array}$

version 1

27 Jan 2015

$?$

1. Carsten Gründemann, Universitätsklinikum Freiburg, Freiburg, Germany

2. Goutam Brahmachari, Visva-Bharati

University, Santiniketan, India

3. Karel Šmejkal, University of Veterinary and Pharmaceutical Sciences, Brno, Czech Republic

Any reports and responses or comments on the article can be found at the end of the article. 
Corresponding author: Atanas G. Atanasov (atanas.atanasov@univie.ac.at)

Competing interests: No competing interests were disclosed.

Grant information: This work was supported by the EU-FP7 Marie Curie Fellowship 252881, and by the University of Vienna “Back-toResearch Grant" (both to R. Liu); as well as by the Austrian Science Fund (FWF): S10704, P25971-B23, and P23317-B11.

The funders had no role in study design, data collection and analysis, decision to publish, or preparation of the manuscript.

Copyright: $\odot 2015$ Liu R et al. This is an open access article distributed under the terms of the Creative Commons Attribution License, which permits unrestricted use, distribution, and reproduction in any medium, provided the original work is properly cited. Data associated with the article are available under the terms of the Creative Commons Zero "No rights reserved" data waiver (CC0 1.0 Public domain dedication).

How to cite this article: Liu R, Heiss EH, Guo D et al. Capsaicin from chili ( Capsicum spp.) inhibits vascular smooth muscle cell proliferation [version 1; peer review: 2 approved, 1 approved with reservations] F1000Research 2015, 4:26

https://doi.org/10.12688/f1000research.6007.1

First published: 27 Jan 2015, 4:26 https://doi.org/10.12688/f1000research.6007.1 


\section{Main text}

Aberrant and accelerated VSMC proliferation is a main contributor to restenosis, the pathological re-narrowing of the vessel lumen after surgical interventions combating vascular stenosis. To overcome restenosis, drug-eluting stents have been developed, aiming at inhibiting VSMC growth by the release of anti-proliferative substances such as paclitaxel and rapamycin. However, these compounds display unresolved issues such as impaired re-endothelialization and subsequent thrombosis induction ${ }^{1}$, which makes the characterization of other compounds able to suppress VSMC proliferation highly relevant. Plant-derived natural products are an excellent resource for identifying lead compounds ${ }^{2}$. Here we examine the anti-proliferative potential of capsaicin, a bioactive component of chili peppers [Capsicum spp. (Solanaceae)], in VSMC.

To test whether capsaicin is able to inhibit proliferation of VSMC induced by PDGF, a major growth factor implied in the aberrant proliferative responses in restenosis ${ }^{3}$, the total amount of metabolically active cells was measured after $48 \mathrm{~h}$ of incubation by the resazurin conversion method ${ }^{4}$. Capsaicin indeed suppressed VSMC proliferation concentration-dependently with an $\mathrm{IC}_{50}$ of $5.36 \mu \mathrm{M}$ (Figure 1A). To confirm the anti-proliferative effect of capsaicin with a second experimental method, we measured DNA synthesis in VSMC by quantification of 5-bromo-2'-deoxyuridine (BrdU) incorporation into DNA. Capsaicin also inhibited PDGF-stimulated DNA synthesis in a concentration-dependent manner with an $\mathrm{IC}_{50}$ of $3.81 \mu \mathrm{M}$ (Figure 1B). To assure that the decreased number of VSMC upon treatment with capsaicin is not due to cytotoxicity, we quantified cell death by measuring cell membrane integrity estimated by lactate dehydrogenase (LDH) activity inside cells and in cell supernatants. No significant cytotoxicity was detected in the investigated concentration range (Figure 1C). In summary, capsaicin is identified as an inhibitor of VSMC proliferation. Further studies are prompted to elaborate the underlying mode of action of this natural product and to investigate its effect in advanced in vivo anti-restenotic models.

Rat aortic VSMC used in this study were purchased from Lonza (Braine-L'Alleud, Belgium) and cultivated in DMEM-F12 (1:1) medium supplemented with $20 \%$ fetal calf serum and gentamycin. Capsaicin and other chemicals were obtained from Sigma-Aldrich (Vienna, Austria).

For the resazurin conversion assay, VSMC were seeded in 96-well plates at $5 \times 10^{3}$ cells/well. $24 \mathrm{~h}$ later, cells were serum-starved for $24 \mathrm{~h}$ to render them quiescent. Quiescent cells were pretreated for 30 min with capsaicin or vehicle $(0.1 \%$ DMSO) as indicated, and subsequently stimulated for $48 \mathrm{~h}$ with PDGF-BB (20 ng/mL). To measure the number of metabolically active VSMC by resazurin conversion $^{4}$, cells were washed with PBS and incubated in serumfree medium containing $10 \mu \mathrm{g} / \mathrm{mL}$ resazurin for $2 \mathrm{~h}$. Total metabolic activity was measured by monitoring the increase in fluorescence at a wavelength of $590 \mathrm{~nm}$ using an excitation wavelength of $535 \mathrm{~nm}$ in a 96-well plate reader (Tecan GENios Pro).
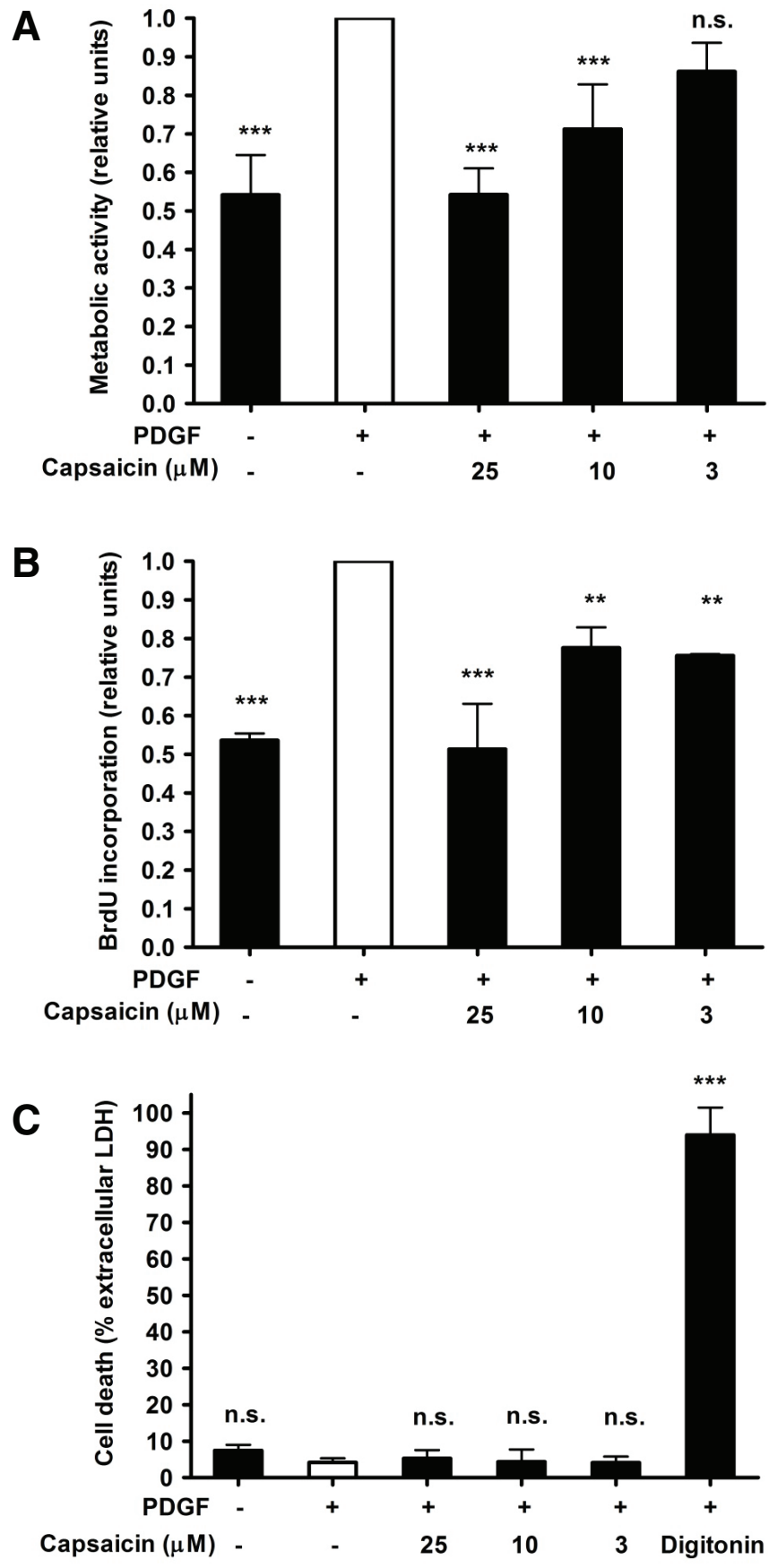

Figure 1. Effect of capsaicin on VSMC proliferation. Cell proliferation was estimated by quantification of metabolic activity $(\mathbf{A})$ and DNA synthesis (B). Cell death was estimated by quantification of the percentage of extracellular LDH $(\mathbf{C})$. Data represent mean \pm $\mathrm{SD}$ from at least three independent experiments (n.s., not significant; ${ }^{* * *} p<0.001 ;{ }^{* *} p<0.01$; ANOVA/Bonferroni). 
For the BrdU incorporation assay, VSMC were seeded and starved as for the resazurin conversion assay. Quiescent cells were pretreated for $30 \mathrm{~min}$ with capsaicin, or vehicle as indicated and subsequently stimulated with PDGF-BB $(20 \mathrm{ng} / \mathrm{mL})$. To estimate de novo DNA synthesis in $\mathrm{VSMC}^{5}$, BrdU was added $2 \mathrm{~h}$ after PDGF stimulation, and the incorporated amount was determined $22 \mathrm{~h}$ afterwards with a BrdU ELISA kit according to the manufacturer's instructions (Roche Diagnostics).

For assessing cytotoxicity, VSMC were seeded and serum-starved as indicated above. The quiescent cells were pretreated for $30 \mathrm{~min}$ with capsaicin, or vehicle as indicated, and subsequently stimulated for $24 \mathrm{~h}$ with PDGF-BB ( $20 \mathrm{ng} / \mathrm{mL}$ ). To quantify the loss of cell membrane integrity as a sign for cell death ${ }^{6}$, the supernatants of the treated cells were assessed for LDH activity. For estimation of the total LDH, identically treated samples were incubated for $45 \mathrm{~min}$ in the presence of $1 \%$ Triton X-100. The released and total LDH enzyme activity was quantified for $30 \mathrm{~min}$ in the dark in the presence of $4.5 \mathrm{mg} / \mathrm{mL}$ lactate, $0.56 \mathrm{mg} / \mathrm{mL}$ NAD+, $1.69 \mathrm{U} / \mathrm{mL}$ diaphorase, $0.004 \%(\mathrm{w} / \mathrm{v}) \mathrm{BSA}, 0.15 \%(\mathrm{w} / \mathrm{v})$ sucrose, and $0.5 \mathrm{mM}$ 2-p-iodophenyl-3-nitrophenyl tetrazolium chloride (INT). The enzyme reaction was stopped with $1.78 \mathrm{mg} / \mathrm{mL}$ oxymate and the absorbance was measured at $490 \mathrm{~nm}$ in a 96-well plate reader (Tecan GENios Pro). Potential effects on cell viability were estimated as percentage of extracellular LDH activity. The cytotoxic natural product digitonin $(100 \mu \mathrm{g} / \mathrm{mL})$ was used as a positive control.

Statistical analysis was performed by ANOVA/Bonferroni test (GraphPad PRISM software, version 4).
Effect of capsaicin on vascular smooth muscle cell proliferation: raw data

3 Data Files

http://dx.doi.org/10.6084/m9.figshare.1289721

\section{Data availability}

Figshare: Effect of capsaicin on vascular smooth muscle cell proliferation: raw data. doi: 10.6084/m9.figshare. $1289721^{7}$

\section{Author contributions}

RL, DG, VMD and AGA conceived the study. RL, EHH and AGA designed and analyzed the experiments. RL performed the experiments. RL and AGA prepared the first draft of the manuscript. All authors critically commented on and revised the draft manuscript and agreed to the final content.

\section{Grant information}

This work was supported by the EU-FP7 Marie Curie Fellowship 252881, and by the University of Vienna "Back-to-Research Grant" (both to R. Liu); as well as by the Austrian Science Fund (FWF): S10704, P25971-B23, and P23317-B11.

I confirm that the funders had no role in study design, data collection and analysis, decision to publish, or preparation of the manuscript.
1. Raja SG: Drug-eluting stents and the future of coronary artery bypass surgery: facts and fiction. Ann Thorac Surg. 2006; 81(3): 1162-71. PubMed Abstract | Publisher Full Text

2. Kinghorn $\mathrm{AD}$, Pan $\mathrm{L}$, Fletcher $\mathrm{JN}$, et al.: The relevance of higher plants in lead compound discovery programs. J Nat Prod. 2011; 74(6): $1539-55$.

PubMed Abstract | Publisher Full Text | Free Full Text

3. Yang XP, Pei ZH, Ren J: Making up or breaking up: the tortuous role of platelet-derived growth factor in vascular ageing. Clin Exp Pharmacol Physiol. 2009; 36(8): 739-47.

PubMed Abstract | Publisher Full Text

4. Kurin E, Atanasov AG, Donath O, et al:: Synergy study of the inhibitory potential of red wine polyphenols on vascular smooth muscle cell proliferation. Planta Med. 2012; 78(8): 772-8.

PubMed Abstract | Publisher Full Text

5. Schwaiberger AV, Heiss EH, Cabaravdic M, et al: Indirubin-3'-monoxime blocks vascular smooth muscle cell proliferation by inhibition of signal transducer and activator of transcription 3 signaling and reduces neointima formation in vivo. Arterioscler Thromb Vasc Biol. 2010; 30(12): 2475-81. PubMed Abstract | Publisher Full Text

6. Fakhrudin N, Waltenberger B, Cabaravdic M, et al:: Identification of plumericin as a potent new inhibitor of the NF- $\kappa B$ pathway with anti-inflammatory activity in vitro and in vivo. Br J Pharmacol. 2014; 171(7): 1676-86. PubMed Abstract | Publisher Full Text | Free Full Text

7. Liu R, Heiss EH, Guo D, et al:: Effect of capsaicin on vascular smooth muscle cell proliferation: raw data. Figshare. 2014.

Data Source 


\title{
Open Peer Review
}

\section{Current Peer Review Status:}

\section{Version 1}

Reviewer Report 02 February 2015

https://doi.org/10.5256/f1000research.6428.r7485

(C) $\mathbf{2 0 1 5}$ Šmejkal K. This is an open access peer review report distributed under the terms of the Creative Commons Attribution License, which permits unrestricted use, distribution, and reproduction in any medium, provided the original work is properly cited.

\begin{abstract}
Karel Šmejkal
Department of Natural Drugs, University of Veterinary and Pharmaceutical Sciences, Brno, Czech Republic

The authors are describing the inhibitory activity of capsaicin on vascular smooth muscle cell proliferation. The article looks to be well written, with adequate data. I miss only a bit deeper discussion of reasons for capsaicin selection for testing.
\end{abstract}

Competing Interests: No competing interests were disclosed.

I confirm that I have read this submission and believe that I have an appropriate level of expertise to confirm that it is of an acceptable scientific standard.

Author Response 28 Apr 2015

Atanas Atanasov, University of Vienna, Vienna, Austria

Thank you very much for taking the time to review our manuscript.

Aiming to identify new inhibitors of VSMC proliferation, we tested a range of natural compounds derived from medicinal plants traditionally used for the treatment of different inflammation-associated conditions (including cardiovascular disease). One of the tested compounds was capsaicin, which revealed activity and therefore was further characterized.

Competing Interests: No competing interests were disclosed.

Reviewer Report 02 February 2015 
(C) 2015 Brahmachari G. This is an open access peer review report distributed under the terms of the Creative Commons Attribution License, which permits unrestricted use, distribution, and reproduction in any medium, provided the original work is properly cited.

\section{Goutam Brahmachari}

Laboratory of Natural Products \& Organic Synthesis, Department of Chemistry, Visva-Bharati University, Santiniketan, West Bengal, India

I have gone through the present manuscript entitled "Capsaicin from chili (Capsicum spp.) inhibits vascular smooth muscle cell proliferation" by Liu et al. with interest where the investigators demonstrated the efficacy of natural capsaicin in overcoming restenosis by using a vascular muscle cell model (VSMC) in vitro.

Besides macrophages, vascular smooth muscle cells (VSMCs) are now also believed to play a significant role in generating foam cells that accumulate cytoplasmic droplets of cholesterol esters and triglycerides leading to atherosclerosis regarded as a prime cause of cardio- and cerebrovascular events. Proliferation of VSMCs thus is a common cause of restenosis among the patients who were previously undergone percutaneous transluminal coronary angioplasty or bypass surgery. Under this purview, the present work demonstrating promising in vitro antiproliferative activity of natural capsaicin seems to be much interesting.

The experiments are straightforward and sufficient in arriving at the conclusions. Representation of facts and organization of the manuscript are praise-worthy. The manuscript may be accepted and indexed in its present form. At the same time, I have a suggestion for the investigators as mentioned below, which may be addressed to make the revised manuscript more demanding.

\section{Suggestion}

Rapamycin and paclitaxel are commonly used standard drugs to resist restenosis in patients although they suffer from certain serious health issues as mentioned by the authors in their present manuscript. Hence, search for better alternative(s) is warranted as a part of which the present work has been developed. Hence, I do suggest comparing the present results with those of at least any one of these two drugs (in addition to or in place of digitonin) to validate superiority of capsaicin.

Competing Interests: No competing interests were disclosed.

\section{I confirm that I have read this submission and believe that I have an appropriate level of expertise to confirm that it is of an acceptable scientific standard.}

Author Response 28 Apr 2015

Atanas Atanasov, University of Vienna, Vienna, Austria

Thank you very much for taking the time to review our manuscript.

Based on the literature, as well as on our own data, the both suggested reference compounds, paclitaxel and rapamycin, are unfortunately more potent than capsaicin. 
Therefore with our short note we did not aim to claim superiority of action, but simply to report a new bioactivity of capsaicin, an interesting natural product with significant dietary and pharmacological relevance.

Competing Interests: No competing interests were disclosed.

Reviewer Report 30 January 2015

https://doi.org/10.5256/f1000research.6428.r7483

(C) 2015 Gründemann C. This is an open access peer review report distributed under the terms of the Creative Commons Attribution License, which permits unrestricted use, distribution, and reproduction in any medium, provided the original work is properly cited.

\section{Carsten Gründemann}

Center for Complementary Medicine, Universitätsklinikum Freiburg, Freiburg, Germany

In the current manuscript, Rongxia Liu et al investigated the influence of the plant-derived natural product capsaicin to overcome restenosis by using a vascular muscle cell model

(VSCM) in vitro.

The manuscript is well written and conclusion is precise. The experiments are straightforward and the presented cell-based model is adequate to investigate such question. Nevertheless, before indexation the comments below have to be improved in a revised version of the manuscript.

\section{Major Comment:}

Main text: The authors mentioned that paclitaxel and rapamycin are used as standard drugs to inhibit VSCM proliferation. For pharmacological testing, it is essential that the authors should compare the investigated capsaicin to a standard therapy (positive control) to get an idea about capsaicin's bio-activity.

\section{Minor Comment:}

Abstract: The authors have to depict more clearly why it is important to investigate new naturalderived compounds to overcome stenosis.

Competing Interests: No competing interests were disclosed.

I confirm that I have read this submission and believe that I have an appropriate level of expertise to confirm that it is of an acceptable scientific standard, however I have significant reservations, as outlined above.

Author Response 28 Apr 2015

Atanas Atanasov, University of Vienna, Vienna, Austria 
Thank you very much for taking the time to review our manuscript.

While reporting a new bioactivity of the interesting natural product capsaicin, the purpose of our short note is not to claim superiority over existing VSMC inhibitors. Based on the literature, as well as on our own data, both suggested reference compounds, paclitaxel and rapamycin, are more potent than capsaicin. Nevertheless, the identification of new effective molecules (e.g., capsaicin) could be of potential interest, since it might serve as a starting point for the synthesis of more potent derivatives with superior bioactivity profiles (e.g., reduced adverse effects in vivo) in the future.

Competing Interests: No competing interests were disclosed.

\section{Comments on this article}

\section{Version 1}

Author Response 31 Mar 2018

Atanas Atanasov, University of Vienna, Vienna, Austria

Thanks a lot to the readers for the interest in our work. You might also find of interest the following thematically related open $\mathrm{PhD}$ positions:

http://inpst.net/two-23-year-phd-student-positions-in-drug-discovery-targeting-cardiovasculardiseases-atherosclerosis-at-ighz-pas-poland/

We would be especially grateful if you could forward this information to potentially interested PhD candidates.

With best wishes,

Atanas

---

International Natural Product Sciences Taskforce

Website: http://inpst.net/

Twitter: https://twitter.com/_INPST

Facebook: https://www.facebook.com/INPST/

ResearchGate: https://www.researchgate.net/project/International-Natural-Product-ScienceTaskforce-INPST

Competing Interests: No competing interests were disclosed. 
The benefits of publishing with F1000Research:

- Your article is published within days, with no editorial bias

- You can publish traditional articles, null/negative results, case reports, data notes and more

- The peer review process is transparent and collaborative

- Your article is indexed in PubMed after passing peer review

- Dedicated customer support at every stage

For pre-submission enquiries, contact research@f1000.com 